\title{
FOLKTALES OF ZHENG HE IN THE MALAY WORLD: TALES AND ANECDOTES
}

\author{
Ku Boon Dar*
}

\begin{abstract}
This article unravels the folktales of the Zheng He armada as it voyaged to the Malay World in the 15th century. Among the tales highlighted are those of the queenfish and durian. Folk literature refers to series of traditional knowledge and cultural beliefs as well as taboos that have been passed down through the generations through oral, written, or symbolic forms. By tracing and navigating through Zheng He's tales using the qualitative analysis approach, the study of the primary and secondary documents associated with Zheng He and his voyage to the Malay World seeks to dispel the notion that they are mere old wives' tales told within the community to entertain and pass time. Instead, the tales and anecdotes of Zheng He's voyage are a valuable resource for practical moral teachings that can be garnered from those stories that relate to the daily lives of the Chinese community in the Malay World. The research findings summarise that understanding Zheng He's folktales is pertinent in the fostering of cultural exchange and the sharing of moral values between China and the Malay World.
\end{abstract}

Keywords: Zheng He, Malay Archipelago, queenfish, durian, moral values and philosophy

\section{Introduction}

Admiral Zheng He or Cheng Ho (born Ma Sanbao, 1371-1433) was a famous seafarer and ambassador of China's peace mission in the history of China's relationship with the Malay World at the beginning of the Ming Dynasty (1368-1644). Seven consecutive goodwill visits within the span of 28 years (1405-1433) by visiting almost 30 states in the Western Ocean, including the Malay World, five centuries ago proved his determination and willingness. ${ }^{1}$ The purpose of the mission was to spread consensus (de 德) with the foreign countries in order to elevate the prestige of the Ming Dynasty and uphold China's Emperor, thereby promoting trade between China and foreign countries. ${ }^{2}$ This was unlike the greed of European sailors armed with imperialist spirit. Zheng He was never rapacious in conquering the places he visited. Zheng He and his crews were always warmly received in every country, as noted by Ma Huan in his poem:

Where the letter from the king of China arrives,

There shall be happiness and excitement,

Rulers of states and chieftains,

Rush to offer their greetings. ${ }^{3}$

According to Dr. H. Abdul Malik Karim Amrullah (1908-1981), better known as Buya Hamka, an Indonesian ulama and philosopher, there were not many weapons in Zheng He's armada. Instead, he came with gratitude to present to the kings he visited. ${ }^{4}$

When viewed in the perspective of time, the voyage took place nine decades before Christopher Columbus (1451-1506) discovered America, earlier than when Vasco de Gama (1469-1524) sailed

\footnotetext{
${ }^{*}$ Ku Boon Dar (PhD), Lecturer, History Programme, School of Distance Education, Universiti Sains Malaysia. Email: kubd@usm.my.

${ }^{1}$ The Western Ocean refers to the western seas of the South China Sea covering Southeast Asia, the Indian Ocean, the Red Sea, and the East Sea. Please see Kong Yuanzhi (2003), Pelayaran Zheng He dan Alam Melayu (The Voyages of Zheng He and the Malay World), Bangi: Penerbit Universiti Kebangsaan Malaysia, p. 11.

2 In addition, Zheng He's voyage is also said to have tracked the Yongle Emperor's uncle, King Zhu Yunwen. After four years of war, on 13 June 1402, Emperor Yongle succeeded in ousting King Zhu Yunwen. It is believed that Zhu Yunwen ran off to the Western Ocean. Emperor Yongle was concerned that the previous king was still alive, and Zheng He's cruising destination is also said to have tracked the Yongle Emperor's uncle, King Zhu Yunwen. See Chan Hok-lam (1988), "The Chien-wen, Yung-lo, Hung-his and Hsuan-te reigns, 1399-1435," in Frederick W. Mote \& Denis Twitchett (eds.), The Cambridge History of China, Vol. 7: The Ming Dynasty, 1368-1644, Part 1, Cambridge: Cambridge University Press, pp. 193-205.

${ }^{3}$ Ma Huan (1433), Ying Ya Sheng Lan (The Overall Survey of the Ocean’s Shores), rpt. 1970. 【《瀛涯勝覧》。】 J.V.G. Mills (trans.), Cambridge: Cambridge University Press, pp. 29-30.

${ }^{4}$ Kong Yuanzhi (2003), Pelayaran Zheng He dan Alam Melayu, p.18. See also H. Muhd Nur Abdur Rahman, "Wahyu dan Akal - Iman Dan Ilmu," Harian Fajar, Makassar, 29 March 2019 <http://www.mail-archive.com/mayapadaprana@yahoogroups.com/msg18364.html>, retrieved April 10, 2019.
} 
from Portugal to India in 1497, and a century earlier than when Ferdinand Magellan (1480-1521) sailed around the world. Yet Zheng He's stories and the experience of his voyage are still preserved from generation to generation verbally among the communities in the Malay World. Stories about Zheng He became important entertainment among the local people especially among Chinese community. ${ }^{5}$ These stories are still told, heard, and passed on from one generation to another orally, as the cultural expression of the community that is related directly to various aspects of life, such as religion and belief, law, economic activity, the family, and the social values (de) of the community. Johannes Widodo offered the opinion that scholars and educators were bound by academic ethics and are therefore responsible for conveying scholastic truth to the younger generation and the public. ${ }^{6}$ The fact is that the Zheng He folktales are a collection of stories that have been passed down from one generation to the next, and the narratives are based not on historical facts but instead reflect a sense of respect from the local people for the contribution of Zheng He in forging a friendship between China and the nations in the Malay World. ${ }^{7}$

Folktales are literary products of a community that promote oral communication (oral literature) produced by the common people and delivered by storytellers. Since the stories were told orally, their dissemination was limited due to the closed geographical nature and the difficulty to intercommunicate. The stories were passed down from one generation to the next as legacies to a limited and closed community. These folktales became a part of the people's life as well as their culture (folklore), which encompasses all life forms. Hence, exaggeration in folktales is common, because it entices listeners. Since oral literature is transmitted by mouth, it cannot avoid added elements due to the constant change of environment. According to Mohd Taib Osman, because folktales are oral literature, art speech or expressive literature refers to all forms of language that contain literature with aesthetic values, which act as a lesson produced by a collective or citizens, not limited to the village community, peasants, or fishermen, but also including people with a writing system and sufficient literature. ${ }^{8}$ Folktales do not present objective evidence of the date they were first created or of the person who first produced them, and they cannot be traced. This is because of the nature of a society, as whatever is conceived in the society is created by its members, which proves that individualism does not exist in a community that practices oral literature. This is directly related to the society's worldview. According to Edward B. Taylor, folk literature reflects the views of its people and their faith. ${ }^{9}$

This article presents the stories often told among the society in the Malay Archipelago, especially among the Chinese, about Zheng He's visit to the Malay World. As was recognized in many writings, Zheng He has played a vital role as the ambassador of China's emperor during the Ming dynasty in forging mutual understanding and friendship between the China's Empire and the Kingdom of Malacca.

The article provides different perspectives to the reader as the analysis is done based on folktales narrated from a generation to another. In the literary tradition of various ethnic groups, folklore is recognized as a source of philosophy, worldview, values and perception of the society. Even though the validity of the content is questionable and can't be justified rationally or academically, many have considered it as a societal ethos. Besides reading factual and historical writings on Zheng He's voyage to Malacca and other parts of Malay World, analyzing other relevant sources such as stories and television series related to Zheng He would complement our understanding.

\footnotetext{
${ }^{5}$ The stories about the voyage of Zheng He to the Western Ocean were made into a book and published. See Luo Mao Deng, Lu Shu Lun \& Du Shao Hua (2005), Sanbao Taijian Xiyang (Stories of Sam Poh to Western Ocean) or simply called Xiyang Jidan (Adventures to the Western Ocean), rpt. Shanghai: Shanghai Guji Chubanshe.【罗惁登, 陆树萹, 竺少华, 《三宝太监西洋记通俗演义》, 以下簡稱 《西洋記》, 上海: 上海古籍出版。】. An e-book version can be found at 〈http://ctext.org/library.pl?if=en\&res=81319>, retrieved March 10, 2019.

${ }^{6}$ Johannes Widodo (2008), "Zheng He and Melaka: Facts and Fiction," paper presented in the Conference on New Dimensions in Humanities Education", panel Zheng He's visit to Southeaxst Asia: Fact and Fiction, NIE/HSSE Singapore, Singapore: 18-19 November 2008. p. 18.

${ }^{7}$ Peng Heling (1959), Sanbao Taijin Xia Xiyang (Kasim Sam Poh to Western Ocean), Xu Yunqiao (annotation), Xingzhou: Shijie Shuju, p. 2.【彭鹤龄原著, 许云樵评注, 《三保太监下西洋》, 星洲: 世界书局。】

${ }^{8}$ Mohd Taib Osman (1976), "Sastera Rakyat, Tinjauan Umum," in A. Bakar Hamid (ed.), Diskusi. Sastera Vol. 1: Sastera Tradisi, Kuala Lumpur: Dewan Bahasa dan Pustaka, pp. 19-31.

${ }^{9}$ See Edward B. Taylor (1874), Primitive Culture, 2 vols., New York: H. Holt.
} 
Hence, this article attempts to scrutinise the stories behind the queenfish and durian, which continue to be the talk of the Malay World. Additionally, an understanding of historical legacies is relevant in the fostering of cultural exchange and the sharing of moral values between China and the Malay World.

\section{Doublespotted Queenfish Tale}

One day, during the 15th century, as Zheng He's fleet was sailing across the Straits of Malacca, suddenly the wind blew violently and turbulent waves terrorised Zheng He's fleet, which hit the reef. ${ }^{10}$ The crash tore a hole in the bottom of Zheng He's ship, and the water flooded the ship, causing it to sway and almost capsize. At that moment, Zheng He raised his hands and prayed to God for their safety. All of a sudden, the violent wind stopped and the waters calmed, as though Zheng He's prayers were answered. Water no longer flooded the decks until the fleet docked safely in Malacca. ${ }^{11}$ As soon as they arrived, they realised a fish was wedged in the hole at the bottom of the ship, which stopped the water from flooding in. Zheng He immediately pulled the fish out and released it back into the sea. It was told that when the fish was held by Zheng He, he left an imprint of five fingers on the fish (please refer to picture 1). After the incident, the people named the fish (in Hokkien or Minnan speech) Shanban Tiao $Y u$ (the boat-jumping fish). ${ }^{12}$ Among the locals, it is known as queenfish (Ikan Talang Bongkok or Talang Lima Jari in Malay); its scientific name is Scomberoides commersonianus. ${ }^{13}$

The queenfish is easily identified by anglers by its oval shape and short head because of a curve on the fisheye and its nozzle-like but blunt mouth. ${ }^{14}$ Its anal fin is connected to forked tails that are longitudinally tailored for their strong swimming. The body is white and slim, with the upper body more bronze green, while the bottom is faded to silver or white. ${ }^{15}$ However, the significant marks on the queenfish are the five oval spots on its body near its sensory line; it is claimed that the spots were the imprints of Zheng He's fingers when he saved the fish by pulling it from the hole at the bottom of his ship to release it. ${ }^{16}$

Picture 1: Queen fish with a row of blotches along its' body

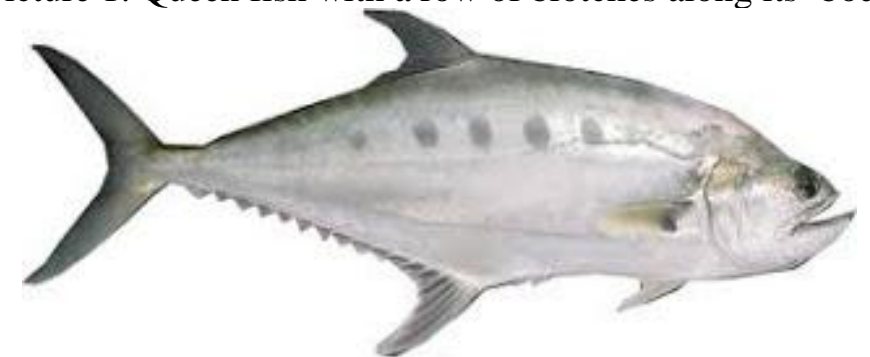

Source: https://www.aynorablogs.com/2016/04/resepi-asam-pedas-ikan-talang-mudah.html

Believing that the queenfish had saved them, the Chinese in Malacca vowed never to consume the fish, and this practice continues. In fact, in Malacca, especially among the Chinese and the Malays, the queenfish is less favoured because it is believed to cause various diseases, especially a skin disease known as 'sawang'. ${ }^{17}$ Joseph Seah told of his experience during the Japanese occupation when he had to consume the queenfish because all the nutritious and high-quality fish were all bought, although he

\footnotetext{
${ }^{10}$ Lei Zongyu (2005), Zheng He Xia Xiyang (Zheng He to Western Ocean), Shanghai: Shaonian Ertong Chubanshe, p. 170. 【雷宗友, 《郑和下西洋》, 上海: 少年儿童出版社。】

${ }^{11}$ Zheng He visited Malacca in 1413-1415, 1417-1419, and 1421-1423. Please see Leo Suryadinata (ed.) (2005), Admiral Zheng He and Southeast Asia, Singapore: International Zheng He Society, Institute of Southeast Asian Studies, p. 37.

12 Yang Kui Kee \& Chan Meow Wah (eds.) (1972), Kamus Umum Bahasa Malaysia (Malay Language General Dictionary), Kuala Lumpur: World Book Company Sdn. Bhd. Queenfish is translated into Chinese as Shanban Tiao Yu (boat-jumping fish 舢舨跳鱼) or Sanbao Gong $Y u$ (Sam Poh Kong fish/Zheng He fish 三保公鱼).

13 The ikan Talang is also known by various names, such as Talang queenfish, giant leatherskin, skinny fish, whitefish, giant dart, and giant queenfish.

${ }^{14}$ Its nozzle mouth caused anglers to call the queenfish 'sour face fish'.

15 The thin-tailed body caused the fish to be known as 'Talang queenfish' among Malaysian anglers, even though 'queenfish' refers to a species of Seriphus politus.

${ }^{16}$ Lee Eng Kew (2019), Zhuan chi Huaren de eyu-Lao Taiping de minjian gushi (The Old Taiping: Tales and Anecdotes), Taiping: Lee Eng Kaw, p. 69.【李永球, 专吃华人的䲞鱼一老太平的民间故事。】

17 Seong Chee Tham (1983), Malays and Modernization: A Sociological Interpretation, Singapore: Singapore University Press, p. 25.
} 
knew of its potential risk of causing skin problems. ${ }^{18}$ His experience proves that queenfish is considered as a last choice by the locals, and its flesh is consumed only when necessary. In 1969, the newspaper Berita Harian also reported of a food poisoning incident which befell a Malay family of five in Kampung Tanjong, Pontian, Johor after consuming the liver of the queenfish. ${ }^{19}$ Fish is rich in nutrients, as it is a source of protein, vitamin D, and minerals, especially omega- 3 fatty acids. ${ }^{20}$ However, queenfish is rarely sold fresh in the local market due to the lack of demand, because its flesh is dull and less meaty. ${ }^{21}$ Moreover, its skin is tough and not easily penetrated by blunt hooks. Its strength, determination, and ability to jump high from the surface of the water means this species of fish rarely swims in mangroves or coral reefs. It usually swims close to the surface and is not easily baited by anglers. Its flat mouth opens wide, and a tail that is very firm and covered in sharp scales could cut into the skin of fishermen. ${ }^{22}$ Most people aren't aware that queen fishes have venomous spikes on their back, in front of the dorsal fin. The spines point out sideways which makes it very easy to get pricked by them when handling with bare hands. The stings are very painful and can last quite a while. ${ }^{23}$ Therefore, the story of the queenfish's deed encouraging the locals to forgo consuming the fish is a myth that cannot be confirmed. There is no scientific evidence of health risks associated with queenfish consumption. In fact, its low quality and agile nature negatively influence the people's demand for the fish.

\section{Delicacies of Durian}

Durian is also one of the main topics in the history of Zheng He's arrival in the Malay World. A story is told of his third voyage to the Malay World in $1409-1411^{24}$ Upon nearing Lieu Lian San (Durian Hill), approximately $2 \mathrm{~km}$ from Tanjong Kepayang beach in Toboali, Bangka Island, ${ }^{25}$ Zheng He's fleet was famished, as their rations were depleted. In addition to a long voyage, they were exhausted, and it was clearly seen in their dispirited faces. Furthermore, they were missing their family even more. As soon as the ships landed on shore, the crews rushed to the jungle in search of food. It is said that they found an awkward-looking fruit, not knowing its name, as it was the first time that they had seen it. The fruit was strange looking with thick skin and sharp, thorny grooves. ${ }^{26}$ Nevertheless, it was taken to the ship. Upon seeing it, Zheng He quickly opened the fruit and shared the flesh with his crews. Some ran away because of the smell, but many enjoyed the fruit and forgot about their sadness. Their faces lit up as soon as they consumed the fruit. Seeing this, Zheng He named the fruit 'liulian'

「流连」. Hence the story of where the fruit got its name. The pronunciation of durian is similar to the pronunciation of 'liu lian「留戀」', which in Chinese means to loiter or refusing to leave and lingering in a place. The word is an extract from the Chinese proverbs (chengyu), which mention 'liu lian wang fan' [流連忘返]. ${ }^{27}$ The literal translation of the word is 'forgetting the desire to go back home'. ${ }^{28}$ However, there are also rumours among the local people that the origin of the name durian

\footnotetext{
${ }^{18}$ Hong Suen Wong (2009), Wartime Kitchen: Food and Eating in Singapore, 1942-1950, Singapore: Editions Didier Millet Pte. Ltd., pp. 71-72.

19 'Lepas makan hati ikan Talang, sa-keluarga pengsan'. Berita Harian, $24 \quad$ February 1969. <http://eresources.nlb.gov.sg/newspapers/Digitised/Article/beritaharian19690224-

1.2.4?ST=1\&AT=search\&k=Ikan\%20Talang\&QT=ikan,talang\&oref=article $>$ retrieved October 20, 2019.

${ }^{20}$ Among the minerals found in fish are iron, copper, zinc, magnesium, and iodine. Please see Takeshi Watanabe \& Viswanath Kiron (1997), “Trace Minerals in Fish Nutrition," Aquaculture, no. 151, p. 186.

21 "Ikan yang Tawar, Buang Kembali ke Laut Sekiranya Berjaya Ditangkap" (Fresh Fish, Throw Back to Seas if Successfully Arrested), New Strait Time, 28 Jun 2011.

22 Pok Mud (1999), "Rahsia Talang" (The Secret of the Talang Fish), Majalah Pancing (Pancing Magazine), August 1999. <http://www.mail-archive.com/mancing-1@kreatif.com/msg21455.html> retrieved March 29, 2019.

23 Handlinefishing.com (2010), Dangerous fishes and sea creatures. <http://handlinefishing.com/whatsthisfish/dangerousfishes.htm] retrieved January 05,2020

${ }^{24}$ Countries visited by Zheng He during his third voyage included Champa, Java, Malacca, Sumatera, Lambri, Kaya, Coimbatore, and Pittanpur. Please see Geoff Wade (trans.) (2012), "Ming Shi Lu" (Veritable Records of the Ming Dynasty), <http://www.epress.nus.edu.sg/msl/place/1105> retrieved March 29, 2019.

${ }^{25}$ Kong Yuanzhi (2003), Pelayaran Zheng He dan Alam Melayu, p. 17.

${ }^{26}$ Han Wai Toon (1948), “Durian in Chinese Accounts,” Journal of the South Seas Society, Vol. 7, no. 13, p. 41. 【韩魏隼， 《流连史 话》, 《南洋学报》。】

${ }^{27}$ Chengyu【成语】 or Chinese proverbs are traditional sayings made up of four Chinese characters.

${ }^{28}$ Roger Blench (2006), "A History of Fruits on the Southeast Asian Mainland," European Association of Southeast Asian Archaeologists (EurASEAA), $\quad$ Bougon $\quad$ September $\quad 26, \quad 8-9$. <http://www.rogerblench.info/Ethnoscience\%20data/History\%20of\%20fruits\%20on\%20mainland\%20SE\%20Asia.mht> retrieved March $12,2019$.
} 
is related to phonetics. ${ }^{29}$ The term durian appears as 'liulian' because the Chinese accent usually pronounces ' $d$ ' as ' 1 '. 30

Indeed, living as a sailor meant having to leave one's homeland for years to navigate and traverse the oceans. Therefore, all sailors have the feeling of being homesick. However, the taste of durian caused them to be happy and forget about returning to their homeland. Thus, the story was passed on from generation to generation amongst the Chinese community. Hence, it was said that the arrival of these early Chinese travellers who braved the high seas and made their way from mainland China to the Malay Archipelago decided to settle and build a life in the archipelago because of their attraction to the durian fruit.

For the Chinese, moral of the story is perhaps that even though durian has a foul smell to some, it is still acceptable. In other words, the story of the durian tries to emphasize that all human beings should be grateful rather than act as the Malay proverb says when the sweetness has been drained, the carcass gets discarded (habis manis, sepah dibuang). The meaning is when something has outlived its usefulness, it then gets discarded. A durian's smells is so distinctive, so pervasive and lingering and has been described variously as rotten onions, turpentine or raw sewage. However, it was the fruit that saves saved their life during their tough days. Therefore, the culture and the way of life in the Malay World are not an obstacle for them, should they wish to settle in the region.

In addition, the durian fruit was said to be enjoyed by women. ${ }^{31}$ When Zheng He stopped in different locations in the Malay World, there was a plague that broke out, and the locals sought his help. He taught them to use durian as medicine, and the result was effective. ${ }^{32}$ Thus, the belief was passed down from generation to generation that the durian fruit had a potent medical effect. In addition, durian fruit is believed to be able to treat the 'chill in the women's hands and feet', especially women who are still in confinement because the body is 'weak' due to the excessive elements of 'ying' (cold).

Therefore, Zheng He once suggested that durian is effective in restoring the body's 'freshness' because the fruit has 'yang' (heat) elements in it. Because of this, the local people sang that 'the goodness of a durian fruit overpowers the goodness of three chickens.' However, to overcome the heat from eating durian, Zheng He taught the locals how to reduce this effect. According to him, after eating the flesh, they need to drink from the shell of the durian filled with water so that the elements of heat can be expelled from the body. ${ }^{33}$

Durian, however, is sometimes a danger to people. This is because when the fruit is ripe, it will fall from the tree almost every hour, and accidents can happen to those who walk or work beneath the durian trees. When the durian falls, the heavy thud can produce a terrible wound, as the sharp thorns of durian fruit can tear the skin of the victim. Death from such accidents is rare, but the victim suffers a small wound. ${ }^{34}$ Because of this miracle, it was rumoured that Zheng He cast a spell on the durian tree. He told the durian tree to guard the safety of its masters and those under it so that they would not be crushed by their sharp thorns. Believing the myth, it can be seen that many locals continue to plant durian trees.

The reputation of the durian fruit was already described in the records of Chinese historical adventures even before Zheng He. In Wang Da Hai's, "Hai Dao Yi Zhi" (Anecdotes of the Oceanic Island), it was noted that:

\footnotetext{
${ }^{29}$ Durian fruit in the Malay Archipelago is called various names according to place and tribe. The Javanese call it dooreen; the Siamese call it turin; and the Burmese call it duyun. Meanwhile, the indigenous people call it shampo, sempa, pendok, and tuang. Please see Wai Toon, "Durian in Chinese Accounts," 41.

${ }^{30}$ Chang Li-chien (1948), “Durio Zibethninus, (L) Murr,” Journal of the South Seas Society, Vol. 7, no. 13, p. 27. 【张礼千, 《榴莲》, 《南洋学报》。】

${ }^{31}$ Wang Dahai (1791), Hai Dai Yi Zhi (Anecdotes of the Oceanic Island), Nan Yao \& Lang Xuan Wu (annotation), rpt 1992. Hong Kong: Xuejin Shudian, p. 38. 【王大海著, 楠姚, 琅璇吴校注, 《海島逸志》, 香港: 学津书店。】

32 Ibid.

${ }^{33}$ Kong Yuanzhi (2007), Muslim Tionghoa Cheng Ho: Misteri Perjalanan Muhibah di Nusantara (Chinese Muslim Cheng Ho: The Mystery of Harmony Journey in the Archipelago), Jakarta: Pustaka Populer, p. 112.

${ }^{34}$ Alfred R. Wallace (2008), The Malay Archipelago, Varick St. NY: Dover Publishing Inc. pp. 56-8.
} 
The durian tree is like the star fruit tree. Its branch is as big as pomelo. When peeled, the fruit is as big as a chicken egg which is white in colour and with a seed. It has a strong and pungent smell. The women love them, but some Chinese despise it and pinched their nose while desperately trying to avoid. ${ }^{35}$

This is similar to the record of Ma Huan (1380-1460), who was Zheng He's follower in his series of voyages to the Malay World. He stated that the durian fruit is:

\begin{abstract}
A type of fruit with a pungent smell known to the local as "du er" or "wu yan" [durian]. ${ }^{36}$ It looks like the Euryale ferox, approximately 8-10 inch in size and covered in long spikes. When it ripens, the fruit will fall to the ground. Inside, there are five to six sections. When overripe, the fruit gives off a strong smell which is similar to a decaying cow's meat. Its seeds look like chestnuts with white flesh; with four to five pieces of fruit in each section. The flesh taste freshly sweet and can be eaten as it is while its seed can be fried. ${ }^{37}$
\end{abstract}

Professor Alfred Wallace (1823-1913), a botanist specialising in tropical fruits who visited Borneo in 1855, once said that a traveller who comes to the Far East must experience the durian fruit firsthand, and only then is their visit considered 'worthwhile' ${ }^{38} \mathrm{He}$ dubbed the durian and mangosteen as the king and queen of fruits. He added that durian is so delicious that the orang utans are also fond of the fruit. ${ }^{39}$

Indeed, the notes of earlier travellers, such as Jan Huyghen van Linschoten in 1599, told of the deliciousness of the durian fruit. According to van Linschoten, anyone who has enjoyed the fruit would say that durian's taste transcends all other fruits in the world. Likewise, Dr Paludanus had a similar opinion that durian is a tropical fruit that is naturally hot and humid. For anyone who has never tasted it, durian is said to smell of overcooked onion, but those who have tried it will be quick to enjoy it again. ${ }^{40}$

Durian is a tropical plant originating in the Southeast Asian region. Its scientific name is Durio zibethinus. It is commonly known as durian because of its hard, sharp-edged shell that resembles a thorn. ${ }^{41}$ It is famously known as the 'king of fruit'. According to nutrition experts, every $100 \mathrm{~g}$ of durian seeds contains $67 \mathrm{~g}$ of water, $28.3 \mathrm{~g}$ of carbohydrates, $2.5 \mathrm{~g}$ of fat, $2.5 \mathrm{~g}$ of protein, $1.4 \mathrm{~g}$ of fibre, and $520 \mathrm{KJ}$ of energy. Durian is also rich in vitamins B1, B2, and C, as well as potassium, calcium, and phosphorus. ${ }^{42}$ Hence, the Zheng He folktale which encourages ladies in confinement to consume the durian fruit was rather accurate considering the beneficial qualities of the fruit itself. On the other hand, the heaty elements in the durian fruit are due to the fact that the fruit contains a variety of vitamins and minerals that give energy in the form of heat in the body.

\title{
Conclusion
}

The folklore from Zheng He's journey to the Malay World has various versions because the dynamics of the stories have changed and become exaggerated or simplified throughout the years. We agree that a storyteller will certainly make a change spontaneously when delivering the stories orally to an audience. However, that is not the main consideration to measure the variation and the richness of stories, let alone ensure the authenticity of stories. What is important to us is that these stories hold information on the cultural system, such as philosophy, values, norms, community behaviour, and the depth of local wisdom. To put it succinctly, these oral traditions are a treasure trove of cultural

\footnotetext{
35 Wang Dahai (1791), Hai Dai Yi Zhi, p. 38.

${ }^{36}$ In Chinese it is written as 【赌尔（乌）(焉)。】

${ }^{37}$ Ma Huan (1433), Ying Ya Sheng Lan, 29-30.【《瀛涯勝覧》。】<http://www.guoxue123.com/biji/ ming/ 0000/081 htm>, retrieved March 11, 2019.

${ }^{38}$ Far East refers to countries located in East Asia. This term is sometimes expanded to include countries in Southeast Asia and South Asia on the grounds that the majority of the population practiced the same culture and religion. Please see Hugh Dyson Walker. (2012). East Asia: A New History. Bloomington: Hugh Dyson Walker, pp. 1-2.

${ }^{39}$ Alfred R. Wallace (2008), The Malay Archipelago, pp. 56-58

40 Ibid and see also Andrea Montanari (2011), The Stinky King: A Social and Cultural History of the Durian, MA Thesis, Southeast Asian Studies Programme, National University of Singapore, pp. 16-18.

${ }^{41}$ Chang Li-chien (1948) "Durio Zibethninus, (L) Murr," p. 35.

42 Michael J. Brown (1997), Durio: A Bibliographic Review, New Delhi: International Plant Genetic Resources Institute, pp. $37-38$.
} 
traditions. Although they are but a small part of the cultural tradition, they play a huge role and offer substantial contribution towards building and shaping the collective thoughts and feelings of the communities in which they thrive. These stories are not only a source of entertainment; they also serve as a reference for education, knowledge, a historical picture of two different nations, and much more. Hence, they must be preserved, recovered, restored, and documented in their various versions. The story of the queenfish relates to the local community's behaviour of expressing gratitude. The story of the durian fruit tells of an episode of the confluence and harmonising of cultures between two continents. The folktales and anecdotes of Zheng He's voyage are laden with values and moral lessons which are practical in nature. It is practical because the instructions can be found in real-life models, such as the queenfish and the durian fruit in these stories.

Acknowledgement: The paper is part of on-going research project supported by the Universiti Sains Malaysia under Research University Grant (RUI) No: 1001/PJJAUH/8016048.

\section{References}

Blench, R. (2006), "A History of Fruits on the Southeast Asian Mainland," European Association of Southeast Asian Archaeologists (EurASEAA), Bougon. Occasional Paper 4. 115-137.

Brown, M. (1997), Durio: A Bibliographic Review, New Delhi: International Plant Genetic Resources Institute.

Tham, Seong Chee (1983), Malays and Modernization: A Sociological Interpretation, Singapore: Singapore University Press.

Dahai, Wang (1791), Hai Dai Yi Zhi (Anecdotes of the Oceanic Island), Nan Yao \& Lang Xuan Wu (annotation). Rpt. 1992. Hong Kong: Xuejin Shudian. 【 王大海著, 楠姚, 琅璇吴校注, 《海島 逸志》，香港: 学津书店。】

Handlinefishing.com (2010), "Dangerous fishes and sea creatures." <http://handlinefishing.com/whatsthisfish/dangerousfishes.htm] retrieved January 05, 2020

Heling, Peng (1959), Sanbao Taijin Xia Xiyang (Kasim Sam Poh to Western Ocean), Xu Yunqiao (annotation). Xingzhou: Shijie Shuju. 【彭鹤龄原著, 许云樵评注, 《三保太监下西洋》, 星洲: 世界书局。】

Hok-lam, Chan (1988), "The Chien-wen, Yung-lo, Hung-his and Hsuan-te reigns, 1399-1435," in Frederick W. Mote \& Denis Twitchett (eds.), The Cambridge History of China, Vol. 7: The Ming Dynasty, 1368-1644, Part 1, Cambridge: Cambridge University Press.

Hong Suen, Wong (2009), Wartime Kitchen: Food and Eating in Singapore, 1942-1950, Singapore: Editions Didier Millet Pte. Ltd.

H. Muhd Nur Abdur Rahman (2019), "Wahyu dan Akal - Iman Dan Ilmu," Harian Fajar, Makassar, 29 March 2019 <http://www.mail-archive.com/mayapadaprana@ yahoogroups.com / msg 18364.html>, retrieved April 10, 2019.

Kui Kee, Yang \& Chan Meow Wah (eds.) (1972), Kamus Umum Bahasa Malaysia (Malay Language General Dictionary), Kuala Lumpur: World Book Company Sdn. Bhd.

Lee Eng Kew (2019), Zhuan chi Huaren de eyu- Lao Taiping de minjian gushi (The Old Taiping: Tales and Anecdotes). Taiping: Lee Eng Kaw. 【李永球, 专吃华人的鳄鱼一老太平的民间故 事。】

Li-chien, Chang (1984), "Durio Zibethninus, (L) Murr," Journal of the South Seas Society, Vol. 7, no. 13.【张礼千, 《榴莲》, 《南洋学报》。】 
"Ikan yang Tawar, Buang Kembali ke Laut Sekiranya Berjaya Ditangkap" (Fresh Fish, Throw Back to Seas if Successfully Arrested). New Strait Time (28 Jun 2011).

Mohd Taib Osman (1976), "Sastera Rakyat, Tinjauan Umum," in A. Bakar Hamid (ed.), Diskusi. Sastera Vol. 1: Sastera Tradisi, Kuala Lumpur: Dewan Bahasa dan Pustaka.

Ma Huan (1433), Ying Ya Sheng Lan (The Overall Survey of the Ocean's Shores), rpt. 1970. 《瀛涯 勝覧》。」J.V.G. Mills (translator). Cambridge: Cambridge University Press.

Mao Deng, Luo, Lu Shu Lun \& Du Shao Hua (2005), Sanbao Taijian Xiyang (Stories of Sam Poh to Western Ocean) or simply called Xiyang Jidan (Adventures to the Western Ocean), rpt. Shanghai: Shanghai Guji Chubanshe.【罗惁登, 陆树崙, 竺少华, 《三宝太监西洋记通俗演义》, 以下簡 稱《西洋記》，上海：上海古籍出版。】

Montanari, Andrea (2011), The Stinky King: A Social and Cultural History of the Durian, MA Thesis, Southeast Asian Studies Programme, National University of Singapore.

Mud, Pok (1999) "Rahsia Talang" (The Secret of the Talang Fish). Majalah Pancing (Pancing Magazine), (August 1999). <http://www.oocities.org/fishing book/talang.html>, retrieved October 10, 2019.

Suryadinata, Leo (ed.) (2005), Admiral Zheng He and Southeast Asia, Singapore: International Zheng He Society, Institute of Southeast Asian Studies.

Taylor, Edward (1874), Primitive Culture, 2 vols, New York: H. Holt.

Wade, Geoff (trans.) (2019), "Ming Shi Lu" (Veritable Records of the Ming Dynasty), <http://www.epress.nus.edu.sg/msl/place/1105>. retrieved October 10, 2019.

Wai Toon, Han (1948), "Durian in Chinese Accounts." Journal of the South Seas Society, Vol. 7, no. 13.【韩魏隼, 《流连史话》, 《南洋学报》。】

Walker, H. D. (2012), East Asia: A New History, Bloomington: Hugh Dyson Walker.

Wallace, A. R. (2008), The Malay Archipelago, New York: Dover Publishing Inc.

Watanabe, Takeshi \& Kiron, Viswanath (1997), "Trace Minerals in Fish Nutrition," Aquaculture, Vol. 151, no. 1-4, 185-207.

Widodo, J. (2008), 'Zheng He's and the shaping of Cosmopolitan cities in Southeast Asia-Melaka case: Facts and Fiction.' Paper presented in the Conference on New Dimensions in Humanities Education, panel Zheng He's Visits to Southeast Asia: Facts and Fiction, organized by NIE/HSSE, Singapore, 18-19 November 2008.

Yuanzhi, Kong (2003), Pelayaran Zheng He dan Alam Melayu (The Voyages of Zheng He and the Malay World), Bangi: Publisher Universiti Kebangsaan Malaysia, 2003.

Yuanzhi, Kong (2007), Muslim Tionghoa Cheng Ho: Misteri Perjalanan Muhibah di Nusantara (Cheng Ho, A Chinese Muslim: The Mystery of Harmony Journey in the Archipelago), Jakarta: Pustaka Populer, 2007.

Zongyu, Lei (2005), Zheng He Xia Xiyang (Zheng He to Western Ocean), Shanghai: Shaonian Ertong Chubanshe.【雷宗友, 《郑和下西洋》, 上海 : 少年儿童出版社。】 